\title{
PENGARUH PEMBELAJARAN ONLINE BERBASIS SPADA, LINGKUNGAN, DAN SARANA PRASARANA TERHADAP MOTIVASI BELAJAR
}

\author{
Dewi Mas'udatul H \\ e-mail: dewihidayah9899@gmail.com \\ Lilik Sri Hariani \\ e-mail: liliksrihariani@unikama.ac.id \\ Walipah \\ e-mail:walipah@unikama.ac.id \\ (Program Studi Pendidikan Ekonomi, Fakultas Ekonomika dan Bisnis, Universitas PGRI Kanjuruhan, \\ Malang)
}

\begin{abstract}
ABSTRAK: Penelitian ini membahas tentang pembelajaran online berbasis SPADA, Lingkungan, dan Sarana Prasarana Terhadap Motivasi Belajar pada mahasiswa Fakultas Ekonomika dan Bisnis Universitas PGRI Kanjuruhan Malang. Penelitian ini bertujuan untuk menganalisis: 1) Pengaruh pembelajara online berbasis SPADA, lingkungan, dan sarana prasarana terhadap motivasi belajar, 2) pengaruh pembelajaran online berbasis SPADA terhadap motivasi belajar, 3) pengaruh lingkungan terhadap motivasi belajar, 4) pengaruh sarana prasarana terhadap motivasi belajar. Penelitian ini merupakan penelitian kuantitatif. Jumlah populasi dalam penelitian ini adalah 330 mahasiswa yang terdiri dari Mahasiswa Fakultas Ekonomika dan Bisnis angkatan 2017 Universitas PGRI Kanjuruhan Malang. Teknik pengambilan sampel yang digunakan yaitu random sampling. Metode pengumpulan data menggunakan angket yang berupa Google Form. Validitas data diperoleh melalui uji coba dari 30 responden di luar sampel. Metode analisis data menggunakan analisis regresi linier berganda. Pada penelitian ini terdapat : Pengaruh pembelajaran online berbasis SPADA, lingkungan, dan sarana prasarana terhadap motivasi belajar, pengaruh pembelajaran online berbasis SPADA terhadap motivasi belajar, pengaruh lingkungan terhadap motivasi belajar, pengaruh sarana prasarana terhadap motivasi belajar.
\end{abstract}

Kata kunci - Pembelajaran Online, Lingkungan, Sarana, Motivasi Belajar.

ABSTRACT: This study discusses online learning based on SPADA, environment, and infrastructure on learning motivation for students of the Faculty of Economics and Business, PGRI Kanjuruhan University, Malang. This study aims to analyze: 1) The effect of SPADA-based online learning, the environment, and infrastructure on learning motivation, 2) the influence of SPADA-based online learning on learning motivation, 3) the influence of the environment on learning motivation, 4) the influence of infrastructure on learning motivation. . This research is a quantitative research. The total population in this study was 330 students consisting of students of the Faculty of Economics and Business class of 2017, Universitas PGRI Kanjuruhan Malang. The sampling technique used is random sampling. The data collection method uses a questionnaire in the form of a Google Form. The validity of the data was obtained through a trial from 30 respondents outside the sample. The data analysis method used multiple linear regression analysis. In this study there are: The influence of SPADA-based online learning, the environment, and infrastructure on learning motivation, the influence of SPADA-based online learning on learning motivation, the influence of the environment on learning motivation, the influence of infrastructure on learning motivation.

Keywords - Online Learning, Environment, Facilities, Learning Motivation. 


\section{PENDAHULUAN}

Pendidikan mempunyai peran penting dalam pembangunan nasional karena pendidikan merupakan salah satu cara untuk membentuk sumberdaya manusia yang berkualitas untuk mencapai tujuan pembangunan nasional (Suwartini, 2017). Seperti yang kita ketahui bahwa setiap jenjang pendidikan mempunyai proses kegiatan pembelajaran sesuai dengan kurikulum yang digunakan. Banyak hal dan faktor yang dapat mempengaruhi kegiatan pembelajaran. Salah satu faktor yang mendukung keberhasilan belajar dalam proses pembelajaran dapat dicerminkan melalui motivasi belajar. Menurut Hanifah (2018) Motivasi belajar sesungguhnya berkaitan erat dengan keinginan peserta didik untuk terlibat dalam proses pembelajaran. Salah satu faktor yang dapat mempengaruhi motivasi belajar adalah diri sendiri. Motivasi ini dapat ditimbulkan seperti adanya keinginan untuk berhasil, dorongan dan kebutuhan dalam belajar dan adanya harapan atau cita-cita untuk masa depan. Selain itu motivasi dapat juga timbul dari luar pribadi peserta didik seperti adanya penghargaan dalam belajar, kegiatan yang menarik dalam belajar maupun lingkungan belajar yang kondusif. Seperti halnya saat ini pembelajaran yang dilakukan secara online memungkinkan mempengaruhi motivasi belajar.

Pembelajaran online merupakan pembelajaran yang menggunakan serta memanfaatkan jaringan internet dalam kegiatan pembelajaran (Isman, 2016). Menurut Kuswanto (2020) dengan adanya pembelajaran online mahasiswa memiliki keleluasan waktu belajar sehingga dapat belajar kapanpun dan dimanapun. SPADA memberikan banyak fitur yang dapat digunakan saat pembelajaran online berlangsung, dengan adanya pembelajaran online berbasis SPADA diharapkan dapat meningkatkan motivasi belajar karena pembelajaran tersebut sangatlah berbeda dengan pembelajaran yang dilakukan dengan tatap muka.

Selain pembelajaran online berbasis SPADA, lingkungan dapat mendorong terhadap peningkatan motivasi belajar. lingkungan memliki pengaruh terhadap motivasi belajar. Dalam hal ini lingkungan tersebut adalah lingkungan belajar (Suwastika, 2017). Hal ini juga selaras dengan pendapat yang dikemukakan oleh (Bejo, 2010) bahwa "berbagai faktor yang mempengaruhi keberhasilan pendidikan dan motivasi belajar adalah siswa sebagai individu dan lingkungan belajar".

Lingkungan belajar memiliki peran dalam menciptakan motivasi mahasiswa dalam belajar. Selain itu lingkungan belajar tidak hanya secara langsung mempengaruhi tinggi rendahnya motivasi belajar, tetapi juga akan menyentuh ranah kognitif (Sumiati, 2012). Lingkungan belajar ini terdiri dari lingkungan keluarga, lingkungan sekolah dan lingkungan masyarakat. Keluarga merupakan lingkungan pertama bagi anak, Karena itu keluarga merupakan lembaga pendidikan tertua, yang bersifat informal dan kodrati (Fuad Ihsan 2011) Oleh karena itu, keluarga selalu dipandang sebagai lingkungan pendidikan yang pertama. Lingkungan masyarakat merupakan lingkungan kedua setelah lingkungan keluarga dan lingkungan sekolah merupakan lingkungan pendidikan formal yang sama-sama mempunyai peran penting dalam mencerdaskan serta memimbing perilaku anak. Selain dibutuhkan dukungan dari lingkungan, juga dibutuhkan adanya sarana prasarana dalam belajar.

Sarana merupakan seluruh perlengkapan yang langsung digunakan dalam proses pembelajaran sedangkan prasarana merupakan kelengkapan yang mendukung proses pembelajaran secara tidak langsung (Bafadal, 2010). Ketersediaan sarana prasarana memungkinkan mempengaruhi terhadap motivasi belajar. Hal ini selaras dengan pendapat yang dikemukakan oleh Wuryani (2012) bahwa "harapan dengan tersedianya sarana prasarana supaya mahasiswa bersemangat, tetapi semua akan sia-sia jika tidak ada motivasi untuk belajar". Karena berdasarkan hasil pengamatan peneliti dari beberapa mahasiswa, terutama saat pembelajaran yang dilakukan secara online banyak dari 
mereka yang terhambat dengan adanya jaringan internet yang tidak stabil sehingga hal tersebut menjadikan kegiatan pembelajaran tidak berjalan dengan lancar.

Berdasarkan latar belakang diatas mendorong peneliti untuk melakukan penelitian dengan judul pengaruh pembelajaran online berbasis SPADA, lingkungan dan sarana prasarana terhadap motivasi belajar pada mahasiswa Fakultas Ekonomika dan Bisnis Universitas PGRI Kanjuruhan Malang" penelitian ini bertujuan: (1)Menganalisis pengaruh pembelajaran online berbasis SPADA, lingkungan dan sarana prasarana terhadap motivasi belajar pada mahasiswa Fakultas Ekonomika dan Bisnis Universitas PGRI Kanjuruhan Malang. (2)Menganalisis pembelajaran online berbasis SPADA terhadap motivasi belajar pada mahasiswa Fakultas Ekonomika dan Bisnis Universitas PGRI Kanjuruhan Malang. (3)Menganalisis lingkungan terhadap motivasi belajar pada mahasiswa Fakultas Ekonomika dan Bisnis Universitas PGRI Kanjuruhan Malang. (4)Menganalisis sarana prasarana terhadap motivasi belajar pada mahasiswa Fakultas Ekonomika dan Bisnis Universitas PGRI Kanjuruhan Malang

\section{TINJAUAN PUSTAKA}

Menurut Lusiana (2020) "motivasi merupakan faktor yang mendorong seseorang untuk melakukan suatu aktivitas tertentu dan motivasi sering kali diartikan sebagai faktor pendorong perilaku seseorang". Segala aktivitas belajar yang menggunakan bantuan teknologi elektronik dengan menggunakan web spada. (Rusman 2012). Menurut Zain Sarnoto (2019) lingkungan merupakan suatu keadaan disekitar kita, baik buruknya lingkungan disekitar kita mempengaruhi faktor-faktor kualitas tingkah laku peserta didik. Menurut Depdikbud sarana prasarana pendidikan adalah "semua fasilitas yang diperlukan dalam proses belajar mengajar baik yang bergerak maupun yang tidak bergerak agar pencapaian tujuan pendidikan dapat berjalan dengan lancar, teratur, efektif dan efisien".

Motivasi adalah perubahan energi dalam diri seseorang yang ditaandai dengan timbulnya perasaan dan reaksi untuk mencapai tujuan (Hamalik, 2011). Menurut Sardiman (2012) macammacam motivasi ada 2 yaitu: Motivasi intrinsik adalah motivasi yang timbul dari diri individu karena dalam diri individu sudah ada dorongan untuk melakukan sesuatu. Sedangkan motivasi ekstrinsik merupakan motivasi yang timbul dari luar diri individu.

Isman (2016) mengungkapkan bahwa dengan pembelajaran yang dilakukan secara online mahasiswa memiliki waktu yang lebih luas sehingga dapat belajar kapanpun dan dimanapun. Mahasiswa dapat berinteraksi dengan dosen menggunakan fitur-fitur yang ada di dalam web SPADA. Menurut Kadir (2012) lingkungan memiliki pengaruh terhadap motivasi belajar. Dalam hal ini lingkungan belajar. Selain itu ketersediaan sarana dan prasarana juga dibutuhkan dalam kegiatan pembelajaran sehingga dapat memungkinkan untuk meningkatkan motivasi dalam belajar. Menurut Hasanah (2020) sarana prasarana yang dibutuhkan dalam pembelajaran online berlangsung meliputi: laptop atau komputer, Handphone, kuota internet dan koneksi jaringan internet. 


\section{METODE}

Rancangan penelitian yang digunakan adalah penelitian kuantitatif. Jumlah populasi sebanyak 330 mahasiswa yang terdiri dari mahasiswa Fakultas Ekonomika dan Bisnis angkatan 2017 Universitas PGRI Kanjuruhan Malang. Dari jumlah tersebut sampel yang diambil sebanyak 66 mahasiswa. Teknik pengambilan sampek menggunakan random sampling yaitu sampel yang di ambil secara acak. Variabel dependen terdiri dari motivasi belajar, sedangkan variabel independen terdiri atas pembelajaran online berbasis SPADA, lingkungan dan sarana prasarana.

Variabel motivasi belajar dapat di ukur oleh beberapa indikator yakni adanya hasrat untuk berhasil, dorongan dalam belajar, cita-cita untuk masa depan, penghargaan dalam belajar, kegiatan yang menarik dalam belajar, lingkungan belajar yang kondusif.

Instrumen dalam penelitian ini menggunakan angket dalam Google Form yang terdiri dari beberapa pernyataan dengan menggunakan skala Likert dengan opsi jawaban sangat setuju sekali (SSS), sangat setuju (SS), setuju (S), tidak setuju (TS), sangat tidak setuju (STS). Uji Asumsi klasik atau uji prasyarat menggunakan uji normalitas, uji multikolinearitas, dan uji heterokedastisitas. Analisis data dalam penelitian ini menggunakan analisis regresi linier berganda dan pengujian hipotesis.

\section{PEMBAHASAN}

Penelitian ini terdiri atas variabel independen yaitu pembelajaran online berbasis SPADA, lingkungan, dan sarana prasarana yang berpengaruh pada motivasi belajar pada mahasiswa Fakultas Ekonomika dan Bisnis Universitas PGRI Kanjuruhan Malang.

Berdasarkan hasil penelitian diketahui bahwa variabel motivasi belajar yang diperoleh dari 66 responden dengan jumlsh 12 soal yang telah dianalisis dinyatakan data valid (sah untuk diproses) dan data yang hilang (missing) adalah nol, nilai rata-rata 41,37, nilai minimumnya 29 dan nilai maksimum 53, dengan demikian motivasi belajar berada pada kategori baik. Untuk variabel pembelajaran online berbasis SPADA yang diperoleh dari 66 responden dengan jumlah 13 soal yang telah dianalisis dinyatakan data valid (sah untuk diproses) dan data yang hilang (missing) adalah nol, nilai rata-rata 49,07, nilai minimumnya 27 dan nilai maksimum 65, dengan demikian pembelajaran online berbasis SPADA berada pada kategori baik. Untuk variabel lingkungan dengan jumlah 16 soal yang telah dianalisis dinyatakan data valid (sah untuk diproses) dan data yang hilang (missing) adalah nol, nilai rata-rata 60,60, nilai minimumnya 37 dan nilai maksimum 78 , dengan demikian Lingkungan berada pada kategori baik. Untuk variabel sarana prasarana yang diperoleh dari 66 responden dengan rincian 19 soal yang telah dianalisis dinyatakan data valid (sah untuk diproses) dan data yang hilang (missing) adalah nol, nilai rata-rata 71,51, nilai minimumnya 44 dan nilai maksimum 92, dengan demikian motivasi belajar berada pada kategori baik.

Sebelum melakukan analisis regresi linier berganda dan pengujian hipotesis, dilakukan uji prasyarat analisis yaitu yaitu melalui uji asumsi klasik yang terdiri dari uji normalitas, uji multikolinearitas dan uji heteroskedastisitas. Hasil dari analisis uji normalitas yang diperoleh menggunakan grafik normal plot disimpulkan bahwa penyebaran data berada di sekitar garis diagonal serta penyebarannya mengikuti arah garis diagnolnya, sehingga data tersebut berdistribusi secara normal.

Hasil dari uji multikolinearitas menunjukkan bahwa pada variabel pembelajaran online berbasis SPADA nilai VIF sebesar 3,238 $<5$ berarti variabel tersebut tidak berkorelasi sempurna, variabel lingkungan nilai VIF sebesar $4,790<5$ berarti variabel tersebut tidak berkorelasi sempurna dan variabel sarana prasarana nilai VIF sebesar $3,647<5$ berarti variabel tersebut tidak berkorelasi sempurna, dengan demikian dapat disimpulkan bahwa ketiga variabel dinyatakan tidak terdapat gejala multikolinearitas. 
Hasil uji heteroskedasitas yang diperoleh menggunakan grafik scatterplot dengan hasil data menyebar secara acak atau tidak membentuk suatu pola tertentu, dengan demikian data tersebut tidak terdapat gejala heteroskedatisitas.

Setelah dilakukannya uji asumsi klasi kemuadian dilakukan analisis regresi linier berganda dengan hasil pada Tabel 1 sebagai berikut:

Tabel 1. Hasil Analisis Regresi Linier Berganda

\begin{tabular}{|c|c|c|c|c|c|c|}
\hline \multirow[b]{2}{*}{ Model } & \multicolumn{2}{|c|}{$\begin{array}{l}\text { Unstandardized } \\
\text { Coefficients }\end{array}$} & \multirow{2}{*}{$\begin{array}{c}\begin{array}{c}\text { Standardized } \\
\text { Coefficients }\end{array} \\
\text { Beta }\end{array}$} & & \multirow[b]{2}{*}{$t$} & \multirow[b]{2}{*}{ Sig. } \\
\hline & $\mathrm{B}$ & Std. Error & & & & \\
\hline 1 (Constant) & 4.567 & 1.658 & & & 2.754 & .008 \\
\hline Pembelajaran Online & .174 & .047 & & .276 & 3.728 & .000 \\
\hline Lingkungan & .203 & .061 & & .332 & 3.351 & .001 \\
\hline Sarana Prasarana & .223 & .043 & & .407 & 5.182 & .000 \\
\hline
\end{tabular}

Berdasarkan Tabel 1. menunjukkan hasil regresi sebagai berikut :

$\mathrm{Y}=4.567+0,174 \mathrm{X} 1+0,203 \mathrm{X} 2+0,223 \mathrm{X} 3$

Persamaan hasil analisis regresi linier berganda tersebut memiliki arti bahwa: (1) konstanta sebesar 4.567 artinya jika variabel pembelajaran online berbasis SPADA, lingkungan dan sarana prasarana nilainya adalah 0, maka motivasi belajar nilainya sebesar 4.567 (2) Koefisien regresi variabel pembelajaran online berbasis SPADA 0,174; artinya jika variabel pembelajaran online berbasis SPADA mengalami kenaikan 1 satuan, maka motivasi belajar akan mengalami kenaikan sebesar 0,174. Koefisien bernilai positif maka pengaruhnya searah dan berhubungan positif. (3) Koefisien regresi variabel lingkungan 0,203; artinya jika variabel lingkungan mengalami kenaikan 1 satuan, maka motivasi belajar akan mengalami kenaikan sebesar 0,203. Koefisien bernilai positif maka pengaruhnya searah dan berhubungan positif. (4) Koefisien regresi variabel sarana prasarana 0,223 artinya jika variabel sarana prasarana mengalami kenaikan 1 satuan, maka motivasi belajar akan mengalami kenaikan sebesar 0,223 . Koefisien bernilai positif maka pengaruhnya searah dan berhubungan positif.

Tabel 2. Hasil Uji F (Uji Secara Simultan)

\begin{tabular}{|c|c|c|c|c|c|}
\hline \multicolumn{6}{|c|}{ ANOVA $^{a}$} \\
\hline Model & $\begin{array}{l}\text { Sum of } \\
\text { Squares }\end{array}$ & Df & Mean Square & $\mathrm{F}$ & Sig. \\
\hline Regression & 2136.856 & 3 & 712.285 & 176.172 & $.000^{\mathrm{b}}$ \\
\hline Residual & 250.674 & 62 & 4.043 & & \\
\hline Total & 2387.530 & 65 & & & \\
\hline
\end{tabular}

Berdasarkan Tabel 2 menunjukkan besarnya nilai Fhitung adalah 176,172 > Ftabel dan nilai signifikasi $0,000<0,05$, maka dapat disimpulkan bahwa $\mathrm{H} 0$ ditolak dan $\mathrm{H} 1$ diterima artinya penelitian pembelajaran online berbasis SPADA, lingkungan dan sarana prasarana secara bersamasama (simultan) berpengaruh signifikan terhadap motivasi belajar pada mahasiswa Fakultas Ekonomika dan Bisnis Universitas PGRI Kanjuruhan Malang.

Berdasarkan hasil dari Uji R square (Kofisien Determinasi) mengidentifikasikan bahwa pengaruh antara varibael pembelajaran online berbasis SPADA, lingkungan, dan sarana prasarana memiliki nilai koefisien korelasi 0,946, artinya variabel bebas pembelajaran online berbasis SPADA, 
lingkungan, dan sarana prasarana secara bersama-sama memiliki hubungan yang kuat dengan variabel terikat motivasi belajar. Nilai koefisien determinasi ( $R$ square) menunjukkan besarnya kontribusi seluruh variabel bebas yaitu pembelajaran online berbasis SPADA, lingkungan, dan sarana prasaran terhadap motivasi belajar, jadi $\mathrm{R}$ square 0,890 memiliki makna pembelajaran online berbasis SPADA, lingkungan, dan sarana prasarana mampu memberikan kontribusi sebesar $89 \%$ terhadap motivasi belajar. Dengan demikian, sisanya dipengaruhi oleh variabel lain diluar variabel yang diteliti.

\section{Pengaruh Pembelajaran Online Berbasis SPADA, Lingkungan, dan Sarana Prasarana Terhadap Motivasi Belajar Pada Mahasiswa Fakultas Ekonomika dan Bisnis Universitas PGRI Kanjuruhan Malang}

Berdasarkan penelitian yang telah dilakukan, dapat diketahui bahwa variabel pembelajaran online berbasis SPADA, lngkungan dan sarana prasarana terdapat pengaruh yang signifikan secara simultan terhadap variabel motivasi belajar pada mahasiswa Fakultas Ekonomika dan Bisnis Universitas PGRI Kanjuruhan Malang, sehingga dalam penelitian ini dapat membuat sebuah hipotesis bahwa pada variabel independen atau variabel bebas secara simultan (bersama-sama) mempengaruhi variabel dependen atau variabel terikat dengan nilai Fhitung sebesar 176,172 dengan tingkat signifikan 0,000, karena nilai Fhitung > Ftabel dan nilai signifikan 0,000 < 0,05 maka Ho1 ditolak dan Ha1 diterima, artinya dapat diambil kesimpulan terdapat pengaruh yang signifikan secara simultan pembelajaran online berbasis SPADA, lingkungan dan sarana prasarana terhadap motivasi belajar dengan nilai $\mathrm{R}$ square sebesar 0,890 yang artinya Pembelajaran online berbasis SPADA, Lingkungan, dan Sarana prasarana memberikan kontribusi sebesar $89 \%$ terhadap Motivasi belajar.

Berdasarkan hasil penelitian rata-rata mahasiswa memiliki motivasi belajar sesuai dengan pernyataan- pernyataan yang ada di angket. Berdasarkan angket yang telah mereka isi mereka mempunyai motivasi belajar dengan berbagai macam faktor ada yang termotivasi dari diri sendiri seperti keinginan untuk berhasil dan adanya harapan atau cita-cita untuk masa depan sehingga mereka terus bersemangat dalam belajar, hal ini sesuai dengan pendapat yang dikemukakan oleh Sardiman (2012). Selain faktor dari diri sendiri ada faktor pendorong dari luar seperti lingkungan belajar yang kondusif. Lingkungan belajar merupakan salah satu komponen paling penting yang terdapat dalam proses pembelajaran. Menurut Irna (2019) mengemukakan bahwa "lingkungan belajar merupakan salah satu faktor yang turut mempengaruhi pertumbuhan serta perkembangan peserta didik". Sehingga lingkungan belajar sangat berperan dalam meningkatkan motivasi belajar, karena kondisi lingkungan yang baik sangat penting dalam mendukung terciptanya motivasi dalam belajar. Tersedianya sarana dan prasarana dapat mendorong keinginan dalam belajar serta menjadikan lebih mudah dalam memahami materi yang diberikan. Apabila sarana prasarana yang tersedia sangat minim maka akan kesulitan dalam belajar. Hal ini sejalan dengan pendapat yang dikemukakan oleh Yuliawan (2014) bahwa "sarana prasarana merupakan hal yang sangat penting dalam menunjang kelancaran serta kemudahan dalam belajar". Selain variabel yang peneliti teliti ada variabel lain yang tidak diteliti dalam penelitian ini seperti pengaruh peran guru dan pola asuh orang tua, jadi dapat disimpulkan bahwa kontribusi variabel independen pada motivasi belajar tergolong cukup tinggi yang artinya pembelajaran online berbasis SPADA, lingkungan dan sarana prasarana berpengaruh bersama-sama terhadap motivasi belajar.

Biasanya mahasiswa yang memiliki motivasi belajar pada diri mahasiswa karena adanya beberapa faktor, seperti faktor pembelajaran yang dilakukan secara online, lingkungan, sarana prasarana seperti yang peneliti teliti pada mahasiswa FEB angkatan 2017 ini. Pembelajaran online berbasis SPADA, lingkungan dan sarana prasarana tersebut sangat berpengaruh terhadap motivasi belajar, diperoleh hasil bahwa kontribusi variabel bebas pada motivasi belajar dikatakan baik. Dari nilai tersebut dapat disimpulkan bahwa motivasi belajar tidak hanya dipengaruhi oleh pembelajaran online berbasis SPADA, lingkungan dan sarana prasarana. Motivasi belajar juga bisa dipengaruhi 
oleh variabel- variabel lain seperti pengaruh peran guru dan pola asuh orang tua. Hal ini sesuai dengan penelitian yang dilakukan oleh Syamsul Darmawan (2018) tentang Pengaruh Lingkungan Sekolah, Peran Guru, Minat Belajar Terhadap Motivasi Belajar.

\section{Pengaruh Pembelajaran Online Berbasis SPADA Terhadap Motivasi Belajar Pada Mahasiswa Fakultas Ekonomika dan Bisnis Universitas PGRI Kanjuruhan Malang}

Hasil penelitian menunjukan bahwa variabel pembelajaran online berbasis SPADA terdapat pengaruh yang signifikan secara parsial terhadap motivasi belajar pada mahasiswa Fakultas Ekonomika dan Bisnis. Pembelajaran online berbasis SPADA sangat mempengaruhi motivasi belajar, karena pembelajaran ini tidak memiliki kesempatan bertatap muka langsung secara fisik antara dosen dengan mahasiswa.

Berdasarkan hasil penelitian rata-rata mahasiswa beranggapan bahwa dengan adanya pembelajaran yang dilakukan secara online memungkinkan ada pengaruh terhadap motivasi belajar sesuai dengan pernyataan- pernyataan yang ada di angket. Berdasarkan angket yang telah mereka isi pada variabel pembelajaran online berbasis SPADA bahwasannya pembelajaran tersebut harus didukung dengan adanya fitur-fitur yang lengkap serta mudah digunakan yang ada di dalam web SPADA. Karena yang terjadi di lapangan mahasiswa terkadang kesulitan ketika mau login ke dalam web tersebut.

Pembelajaran online memungkinkan untuk menggunakan metode pembelajaran yang tepat. Salah satu penerapan yang dapat dilakukan dalam pembelajaran online adalah pembelajaran berbasis SPADA. Pembelajaran online berbasis SPADA memberikan peluang bagi mahasiswa dari satu perguruan tinggi dapat mengikuti mata kuliah bermutu dari perguruan tinggi lain dan hasil belajarnya dapat diakui oleh perguruan tinggi tempat mahasiswa tersebut terdaftar (Kemenristekdikti, 2015). SPADA memiliki tujuan yakni untuk meningkatkan pemerataan akses terhadap pembelajaran yang bermutu di Perguruan Tinggi. Sehingga Kemenristek Dikti juga menerapkan beberapa ketentuan untuk SPADA agar pembelajaran tersebut tetap bisa berjalan dengan semestinya meskipun dilakukan secara online.

Hasil penelitian ini selaras dengan penelitian yang telah dilakukan oleh I Wayon Suwastika (2018) tentang Pengaruh Pembelajaran Online Berbasis Teknologi Informasi Terhadap Motivasi Belajar Mahasiswa STIKOM Bali.

\section{Pengaruh Lingkungan Terhadap Motivasi Belajar Pada Mahasiswa Fakultas Ekonomika dan Bisnis Universitas PGRI Kanjuruhan Malang}

Hasil penelitian menunjukkan bahwa variabel lingkungan terdapat pengaruh yang signifikan secara parsial terhadap motivasi belajar pada mahasiswa Fakultas Ekonomika dan Bisnis Universitas PGRI Kanjuruhan Malang. Lingkungan juga dapat mempengaruhi motivasi belajar yang meliputi kondisi lingkungan baik fisik maupun sosial pembelajaran. Sehingga berhasil tidaknya suatu pembelajaran ternyata juga didukung oleh faktor lingkungan.

Berdasarkan hasil penelitian rata-rata mahasiswa memiliki motivasi sesuai dengan pernyataan- pernyataan yang ada di angket. Berdasarkan angket yang telah mereka isi pada variabel lingkungan bahwasannya lingkungan sangat berpengaruh terhadap motivasi belajar. lingkungan belajar yang terdiri atas lingkungan keluarga, lingkungan sekolah dan lingkungan masyarakat. Kelancaran proses pembelajaran sangat ditentukan oleh kondisi lingkungan belajar. Jika lingkungan belajar sangat mendukung, maka saat kegiatan pembelajaran pun mahasiswa akan lebih bersemangat. Hal ini sesuai dengan pendapat yang dikemukakan oleh Hamalik (2010: 112) yang menyatakan bahwa salah satu faktor yang dapat meningkatkan motivasi belajar adalah lingkungan belajar yang kondusif.

Suasana lingkungan belajar memiliki dampak terhadap kegiatan pembelajaran, para ahli menyebut bahwa lingkungan belajar merupakan sebuah lingkungan pendidikan. Suasana lingkungsn belajar yang kondusif akan timbul apabila di dalamnya terjalin dengan baik seperti saling 
tolong menolong, saling tenggang rasa antara satu sama lain, patuh terhadap norma-norma ataupun tata tertib yang berlaku (Dariyo, 2013). Lingkungan belajar dapat meningkatkan keefektifan belajar sehingga secara tidak langsung akan mempengaruhi tinggi rendahnya motivasi dalam belajar (Sumiati, 2013). Lingkungan bisa mempengaruhi motivasi belajar karena rata-rata seorang mahasiswa cenderung memiliki motivasi dalam belajar ketika ada dukungan dari suasana lingkungan belajar yang kondusif dan membuatnya nyaman sehingga menjadikan mereka lebih bersemangat lagi dalam belajar. Hal ini telah dibuktikan oleh peneliti yang dilakukan di Fakultas Ekonomika dan Bisnis.

Penelitian ini sejalan dengan penelitian yang dilakukan oleh Ika Yuni Nastiti (2013) tentang Pengaruh Lingkungan Terhadap Motivasi Belajar..

\section{Pengaruh Sarana Prasarana Terhadap Motivasi Belajar Pada Mahasiswa Fakultas Ekonomika dan Bisnis Universitas PGRI Kanjuruhan Malang.}

Hasil penelitian menunjukan bahwa variabel sarana prasarana terdapat pengaruh yang signifikan secara parsial terhadap motivasi belajar. Hal ini dibuktikan dari hasil perhitungan analisis regresi diketahui bahwa terdapat pengaruh sarana prasarana terhadap motivasi belajar. Selain pembelajaran secara online dan lingkungan ternyata sarana prasarana juga dapat mempengaruhi motivasi belajar. Hal ini terjadi karena dengan tersedianya sarana prasarana yang lengkap sehingga memudahkan pengajaran dan pembelajaran,

Berdasarkan hasil penelitian rata-rata mahasiswa memiliki motivasi belajar sesuai dengan pernyataan- pernyataan yang ada di angket. Berdasarkan angket yang telah mereka isi pada variabel sarana prasarana bahwasannya sarana prasarana berpengaruh terhadap motivasi belajar. Sarana prasarana berpengaruh terhadap motivasi belajar karena dengan adanya sarana prasarana dapat menunjang serta memudahkan dalam kegiatan pembelajaran.

Sarana prasarana merupakan faktor penting dalam kegiatan pembelajaran. Sarana prasarana yang tersedia dengan lengkap mampu meningkatkan minat dan motivasi dalam belajar. Apabila sarana prasarana yang tersedia sangat minim atau bahkan tidak tersedia sama sekali maka mahasiswa akan kesulitan untuk menerima pembelajaran yang disampaikan. Hal ini sesuai dengan pendapat Yuliawan (2014: 75) bahwa sarana prasarana merupakan hal yang sangat vital dan sangat penting dalam menunjang kelancaran dan kemudahan dalam proses pembelajaran. Aspek keberhasilan dalam pelaksanaan pembelajaran online dilihat dari sumber daya manusia, ketersediaan sarana prasarana dan teknis implementasi pembelajaran (Wahyono et al., 2020).

Kondisi yang terjadi di lapangan, dalam pelaksanaan pembelajaran online seringkali ditemukan kendala. Salah satunya adalah terdapat gangguan penggunaan sarana sebagai pendukung proses belajar. Kondisi tersebut selaras dengan hasil riset Kementrian Pemberdayaan Perempuan dan Perlindungan Anak pada bulan Maret 2020 yang menyatakan bahwa 58\% dari 29 provinsi di Indonesia tidak suka melaksanakan program belajar dari rumah (Kemenppa, 2020). Peserta didik tersebut menganggap terdapat beberapa faktor seperti mengalami keterbatasan teknologi sebagai sarana penunjang program belajar dirumah berupa fasilitas internet, gawai, dan buku elektronik (Satriawan, 2020). Kondisi demikian juga terjadi pada mahasiswa di FEB angkatan 2017, hasil dari penelitian ada beberapa dari mereka yang mengalami kendala sulitnya jaringan internet sehingga hal tersebut menjadikan motivasi dalam belajar menjadi turun.

Penelitian ini sejalan dengan penelitian yang dilakukan oleh Putri Wahyu Lestari (2020) tentang Pengaruh Sarana Prasarana dan Kinerja Guru Terhadap Motivasi Belajar. 


\section{KESIMPULAN}

Berdasarkan hasil dari penelitian dan pembahasan yang telah diuraikan maka dapat diambil kesimpulan, yaitu: 1) terdapat pengaruh yang signifikan secara simultan antara pembelajaran online berbasis SPADA, lingkungan, dan sarana prasarana terhadap motivasi belajar pada mahasiswa Fakultas Ekonomika dan Bisnis Universitas PGRI Kanjuruhan Malang; 2) terdapat pengaruh yang signifikan secara parsial antara pembelajaran online berbasis SPADA terhadap motivasi belajar pada mahasiswa Fakultas Ekonomika dan Bisnis Universitas PGRI Kanjuruhan Malang; 3) terdapat pengaruh yang signifikan secara parsial antara lingkungan terhadap motivasi belajar pada mahasiswa Fakultas Ekonomika dan Bisnis Universitas PGRI Kanjuruhan Malang; 4) terdapat pengaruh yang signifikan secara parsial antara sarana prasarana terhadap motivasi belajar pada mahasiswa Fakultas Ekonomika dan Bisnis Universitas PGRI Kanjuruhan Malang

\section{DAFTAR PUSTAKA}

Ahmad Zain. (2019). Pengaruh Kecerdasan Emosional Dan Lingkungan Belajar Terhadap Motivasi Belajar Siswa SMAN 3 Tangerang. Jurnal Pendidikan Islam Vol 1 No 1 (2019).

Aryuna Dini. (2020). Sarana Dan Prasarana Dalam Mendukung Pembelajaran Daring Pada Masa Pandemi Covid-19. Jurnal Pendidikan Vol 2 No 1 (2020).

Bahrudi Efendi. (2019). Pengaruh Fasilitas Belajar dan Lingkungan Belajar Terhadap Motivasi Belajar. Jurnal Publikasi Pendidikan. Vol 9 issue 1 (2019):46

Chang, I-Ying, (2012). The Effect of Student Learning Motivation On Learning Satisfaction. International Journal Of Organizational Innovation. Vol 4 Issue 3.

Hesti Mutiara. (2019). Pengaruh Lingkungan Keluarga Dan Ketersediaan Sarana Prasarana Terhadap Motivasi Belajar Siswa SMK Batik 1 Surakarta. Jurnal Informasi dan Komunikasi Vol 3 No 2 (2019).

Irma E. (2019). Pengaruh Lingkungan Kampus Terhadap Motivasi Belajar Mahasiswa Fakultas Ekonomi Universitas Sisingamangaraja XII Tapanuli. Jurnal Pendidikan Vol 1 No 2 (2019)

Irwanto. (2020). Pelaksanaan Pembelajaran Online Di Program Studi Pendidikan Vokasional Teknik Elektro Untirta Di Masa Pandemi Covid-19. Jurnal Pendidikan Vokasional. Vol 3 No 1 (2020).

Kemendikbud. (2013). Permendikbud No 109 tentang Penyelenggaraan Pendidikan Jarak Jauh Pada Pendidikan Tinggi. Jakarta: Kementrian Pendidikan dan Kebudayaan.

Kemenppa. (2020). Mendengar Suara Anak Indonesia Tentang Covid-19 Melalui Survei AADC-19. Kemenppa.Go.Id

Kusumaningrum, Diana. (2017). Pengaruh Sarana Prasarana dan Teman Sebaya Terhadap Motivasi Belajar Dalam Ekonomi XI IPS Mayoga. Jurnal Economia. Vol 6 No 2 (2017): 175-180.

Lestari Eka Karunia. (2014). Implementasi Brain-Based Learning Untuk Meningklatkan Kemampuan Koneksi Dan Kemampuan Berfikir Kritis Serta Motivasi Belajar Siswa SMP. JUDIKA (JURNAL PENDIDIKAN UNISKA) Vol 2 No 1.

Lusiana Fina. (2021). Dampak Pembelajaran Online Terhadap Motivasi Belajar. Jurnal Pendidikan Vol 7 No $3(2021)$

Nepal, Bijaya. (2015). Effect of School's Physical Facilites on Learning and Outcomes of Student in Nepal. Journal for studies in Management and Planning. Vol 1 issue 6 (2015):226-279.

Sumiati. (2012). Pengaruh Lingkungan Belajar Siswa Terhadap Motivasi Belajar dan Implikasinya. Jurnal Pendidikan Ekonomi dan Koperasi, Vol 7 No 1.

Utomo, Prio Danang., \& Madji, Zainul. (2017). Pengaruh Lingkungan Belajar dan Peran Guru Terhadap Motivasi Belajar. Jurnal Pendidikan Ekonomi. Vol 1 No 1 (2017): 1-7 
Wahyono, P., Husamah, H., \& Budi, A, S. (2020). Guru Professional Di Masa Pandemi Covid-19: Review implementasi, tantangan, dan solusi pembelajaran daring. Jurnal Pendidikan Profesi Guru, 1(1), 51-65.

Wang Ning and Chia-Ching Tu (2019) Influence Of Learning Motivation Of Mainland Chinese Students To Universities In Thaiwan On Career Adaptability: With Future Time Perspective As Mediator. Journal Of Education Studies, Volume 4 , Issue 2.

Witkin, H. A., Moore, C. A., Goodenough, D. R.m \& Cox, P.W. (2011). Field-dependent and fieldindependent cognitive style and their educational implications. Review of Education Research. 